\title{
MAG wt Allele
}

National Cancer Institute

\section{Source}

National Cancer Institute. MAG wt Allele. NCI Thesaurus. Code C142151.

Human MAG wild-type allele is located in the vicinity of $19 q 13.12$ and is approximately 22 $\mathrm{kb}$ in length. This allele, which encodes myelin-associated glycoprotein, is involved in axon myelination. Mutation of the gene is associated with autosomal recessive spastic paraplegia 75. 